\title{
Impact of Entrepreneurship Training on Poverty Reduction Among Rural Youths
}

\author{
Silas Titus NGUWAP \\ Department of Office Technology and Management, Plateau State Polytechnic, BarkinLadi
}

\begin{abstract}
The study examined the impact entrepreneurship training on poverty reduction among the rural youths in Bokkos Local Government Area of Plateau State, Nigeria. Twospecific purpose and research questions were raised for the study. The study adopted mixed method research design. Both quantitative and qualitative methods were used. The population of the study comprise youths across the districts in Bokkos Local Government Area of Plateau State. A sample of 245 youths was selected from the population of the study. The identified stratum was the districts in Bokkos Local Government Area of Plateau State. Entrepreneurship Training and Poverty Reduction Questionnaire (ETPRQ) was used to gather the quantitative data before the training. Focus group discussion with the youths after the training was used to gather the qualitative data for the study. The instruments were duly validated and Cronbach Alpha reliability coefficient of 0.81 was calculated for the questionnaire. The quantitative data collected were analysed using mean and standard deviation for the research questions while the qualitative data were analysed using content analysis. The findings revealed among that entrepreneurship training has positive impact on the entrepreneurial skill acquisition for poverty reduction among youths. It was concluded that entrepreneurship training had positive impact on poverty reduction among youths. Based on the findings of the study, the following recommendations are made among others: Government at all levels, Non-governmental organizations and philanthropist should organize entrepreneurship training programme for youths to acquire relevant entrepreneurial skills which will go a long way to reduce poverty among the youths.
\end{abstract}

Keywords: Entrepreneurship, Training, poverty, Reduction, Rural, Youths

DOI: $10.7176 / \mathrm{JEP} / 11-21-08$

Publication date:July $31^{\text {st }} 2020$

\section{Introduction}

The creation of a country's wealth and dynamism depends upon the competitiveness of its firms and this, in turn, relies fundamentally on the capabilities of its entrepreneurs and managers. The issue of poverty eradication has been a top priority of many government institutions, especially in developing countries where extreme poverty is conspicuous and become pandemic. In Nigeria today, the prevailing down swing of the economy with its attendant poverty, unemployment, corruption, poor sources of revenue and lack of social welfare provision and social vices have profound advert effect on day to day lives and many families.

These have become worrisome to the government and to every wellmeaningful citizen of Nigeria. Though government policies aimed at economic development are claimed to be directed at the rural poor, little or nothing is seen in tangible form to lighten their predicament. The United Nations having realized these problems, have been in the realized these problems have been in the forefront of partnering with nations especially the developing ones to ensure the realization of its Millennium Development Goals of halving poverty by the year 2020. These goals become the link-chain in Nigeria's on-going initiatives and process under the New Partnership for African Development (NEPAD) and the National Economic Empowerment and Development Strategy (NEEDS). According to the MDG Report, (2004), a nation's first goal must be to eradicate poverty and satisfy the priority needs of her citizenry in a way that will not jeopardize the opportunity for the future generations to attain the same objectives.

The rate of poverty in the present Nigeria is however, accentuated by the increasing rate of unemployment, high level of illiteracy, corruption, psychological and physical problems including despair, illusion, low selfesteem, hallucination and total depression as well as mental instability and bad governance among others. Youth entrepreneurship is one of the ways that can be used to reduce poverty, youth unemployment and underemployment. Effective entrepreneurship in this context is the process of teaching and encouraging young entrepreneurs to create new enterprises, new commercial activities and new economic sectors and sustain them. Young people tend to have higher business growth aspirations than older entrepreneurs, as they want their businesses to grow quicker, thereby creating new jobs for others. Successful young entrepreneurs can also be inspiring role-models for other young people thereby increasing future entrepreneurship development (Youth Entrepreneurship, 2012). Globallyyoung people are facing tremendous challenges most notably the unprecedented levels of unemployment in both developed and developing countries that were spurned by the 2008 economic crises. Since this 2008 crises, the number of unemployed youths has soared to an estimated 73.4 million young people, - (12.6 percent) of the total youth population in Nigeria, reporting an increase of 3.5 million between 2007 and 2013, and projected to rise to 12.8 percent of the total youth population in 2018. (ILO, 2013). 
However, youth entrepreneurship faces a variety of barriers, and this study hopes to expose the youths to a number of strategies to overcome such barriers so as to equip them with competences required for effective entrepreneurship development for success in today's fast changing world of economic meltdown in Nigeria.The findings of this study will be of benefit to aspiring entrepreneurs, particularly the youths because it will help them by acquainting them with proper entrepreneurial skills to commence and sustain their businesses and reduce poverty to a minimal level. It will also help them to generate jobs for others, produce goods and services for the society, introduce new technologies, improve or lower cost outputs and earn foreign exchange through export expansion of local and other produce. The study will also help education administrators to include in the curriculum how the rural youths in Nigeria would be trained towards effective entrepreneurship development.

This study will mobilize domestic savings and utilization of human initiatives thereby making the rural youths become self-reliant and useful to themselves and the Nigeria economy.Poverty has been defined by different authors. Kankwenda (2002) defined poverty as: A multidimensional phenomena influenced by a wide range of factors, these includepoor people lack of access to income earning and productive activities and to essential social services. The Copenhagen Declaration of 1995 seems to shed more light on what really constitutes poverty, when its assets:

Poverty has various manifestations, including lack of income and productive resourcessufficient to ensure sustainable livelihood; hunger and malnutrition, ill health; limited or lackof access to education and other basic services, increase morbidity and mortality from illness,homelessness and inadequate housing; unsafe environments, social discriminations andexclusion. It is also characterized by a lack of participation in decision and in civil, social and cultural life (Edoh 2003).

Umoru et al, (2016) defined poverty as not having enough money to meet basic needs including food, clothing and shelter. However, poverty is much more than just not having enough money. The notion of poverty is determined in different ways by different institutions. To Adejo (2006) poverty can be manifested in poverty of history, poverty of intellect and poverty of ideology. In any case the deprived are usually the poor. These are people of insufficient income, inadequate food intake, lack basic healthcare, lack shelter and safe drinking water, poor environmental cleanliness, lack access to basic education and skills, ignorant of fundamental human rights, and access to information.

According to Madsen (2007) entrepreneurship is the ability some people have to accept risks and combine factors of production in order to produce goods and services. It can also be seen as the willingness and ability of an individual to seek investment opportunities in the environment and be able to establish and run an enterprise successfully based on the identified opportunities. This implies that for entrepreneur to succeed he must have the capacity to seek the environment for economic opportunities that will increase its economic value in business and the economic growth of the society in general. Wang (2008) argues that an entrepreneur is a human builder, who can convert a stumbling block into a stepping stone. To an entrepreneur, there is no mountain that is unmovable. $\mathrm{He}$ is a creative and aggressive innovator who promotes is the necessary relationships required for the new business to come into existence. He is a risk bearer, he starts a business and brings about improvement on the methods of doing things and in that process, generates employment opportunities for the teaming population. According to Leedy and Ormrod (2009) entrepreneurship is the process of identifying an opportunity related to needs, satisfaction and converting it to a thing (product or services) of value.

According to Etonyeaku (2009), entrepreneurial Skills can be described as the necessary set of skills required to be an entrepreneur. In other words, entrepreneurial skills are those essential skills an entrepreneur needs to run a business or add value to work successfully. Skill is defined as the rapidity, precision, expertise, dexterity, and proficiency exhibited through mental and manual repetition of performance of an operation. It is a well-established habit of doing something through the acquisition of performance capabilities. The author maintains that skill is the capacity of a person to accomplish a task with desired precision and certainty.Entrepreneurial skills are associated with competence in the process of opportunity identification, the ability to capitalize on identified opportunities and a range of skills associated with competence in the process of opportunity identification (Orah, 2019). There are three main groups of skills required by the entrepreneur according to Economic Cooperation and Development (ECD 2010), these group of skills are: Technical Skills: Such as communication, environment monitoring, problem solving, technology implementation and use, interpersonal and organizational skills. Business management skills such as, planning and goal setting, decision making, human resource management, marketing, finance, accounting, customer reflection, quality control, negotiation, business launch, growth management, compliance with regulations skills.

\section{Statement of the Problem}

The issue of poverty has become worrisome global phenomenon. Ajulor, (2013) estimated that about 1.2 billion people are living below one dollar per day. The case of Nigeria appears to fall in the category of high-level poverty; Nigeria as a country has over $70 \%$ of its population to be poor and about $60 \%$ living in absolute poverty (Saba, 
Mamman, Saba \& Mustapha, 2020). Of this number, youths are not left out because many of them are unemployed. Unemployment is a major cause of poverty among the youths. This is an economic problem not only in Nigeria but all over the world. Several measures have been taken by successive Nigeria governments to reduce this economic menace of poverty by reducing unemployment. One of these measures is the introduction of entrepreneurship. Youths are encouraged to start-up small-scale businesses to help better their lives and boost the nation's economy. Youth entrepreneurship is very vital to the economy of a nation with respect to economic development and poverty reduction. Creation and sustenance of small-scale businesses are identified as the engine room of the growth of the economy. The population of Nigeria consist more of youths than any other group. There is no doubt that when majority this group embark on entrepreneurship, the country's economy will be better.

However, there is a low rate of entrepreneurship in the country especially among the youths. Everybody prefers to look for jobs which are not available. Even the few available small-scale businesses are prone to failure due to the dearth of certain qualities needed by the businesses, their owners and managers (Bannock, 2008). In Plateau State, entrepreneurial ventures have a low survival rate as entrepreneurs start businesses but are unable to turn them into sustainable operations, especially, in Bokkos Local Government Area. This area has very low level of entrepreneurial activities, hence the high poverty rate. The failure of these enterprises might not be unconnected with a lot of impediments lack of skills for effective entrepreneurship development among the youths.Also, it was observed that most new small-scale businesses in the state do not move from the first stage of existence to other stages of survival and success.

The researcher's observation and interaction with the youths revealed that most of the youths are not willing to embark on any entrepreneurial venture. Some of them complained that they do not possess the skills to be successful in entrepreneurship. Others said that entrepreneurship ventures always failed, so why would they embark on what they know already will fail. The type of entrepreneurship venture to enter into was also their concern.

It is against these reasons that this study was conducted to determine the impact of entrepreneurship training on poverty reduction among youths in Bokkos Local Government area of Plateau State. There are many studies on entrepreneurship, but to the best knowledge of the researcher, no study have attempted to look at the impact of entrepreneurship training on acquisition of entrepreneurial skills, willingness to embark on entrepreneurship, identification of signs of business failure and strategies to avoid business failure as indices of poverty reduction.The findings of this study will enable youths in to understand and focus on implementing the key business practices and adopting the key entrepreneurial skills that can lead their businesses to long-term survival. Achieving this will contribute to the reduction of the high small-scale business failure rates and increase small scale businesses long-term thereby reducing poverty among the youths.

\section{Research Questions}

The following research questions were raised to guide the study.

1. What is the perception of youths on the level of entrepreneurial skills needed for business creation and sustenance before the training in Bokkos LGA of Plateau State?

2. What is the impact of entrepreneurship training experiences on the entrepreneurial skills acquisition for business creation and sustenance to reduce poverty among youths in Bakkos LGA of Plateau State?

\section{Methodology}

The study adopted mixed method research design. Both quantitative and qualitative methods were used. This design helps the researcher to triangulate the data gathered in the course of data analysis. The researcherwas able to confirm and explain the information from the two methods. The quantitative data were gathered by means structured questionnaire while the qualitative data were gathered through focus group discussion. The quantitative data were collected before the training and the qualitative dataafter the training. The population of the study comprise youths across the districts in Bokkos Local Government Area of Plateau State.A total sample of 245 youths was selected from the population of the study. The sample was selected using stratified random sampling technique. The identified stratum was the Districts in Bokkos Local Government Area of Plateau State.The instruments used for data collection wereEntrepreneurship Training and Poverty Reduction Questionnaire (ETPRQ) designed by the researchers and Focus group discussion with the youths after the training. The questionnaire was used before the training. The questionnaire consisted of closed-ended questions. The questionnaire consists of 10 items on youths' perception of the entrepreneurial skills needed(before the training). All the items are placed on a four-point rating scale of measurement ofVery Highly Needed (VHN), Highly Needed $(\mathrm{HN})$, Moderately Needed (MN) and, Not Needed (NN). The items were scored using 4, 3, 2 and 1, respectively.

The instrument for gathering the qualitative data was focus group discussion. The focus group discussion guide was designed by the researcher and is made up of twoopen-ended questions. The questions were meant to solicit the responses of the participants on the impact of the training received on the entrepreneurial skills acquiredfor poverty reduction. The focus group discussion was conducted face-to-face during the final session of 
the training. English and Hausa languages were the media of communication for the discussion, because some of the participants were fluent in English language. Ethical considerations such as informed consent, voluntary participation, and confidentiality were considered. The data from the focus group discussion was audiotape on the permission of the participants. The discussion lasted for two hours. The questionnaire and focus group discussion guide were validated by three experts. The Cronbach alpha method was used to determine the reliability of the instrument and the reliability coefficient of 0.82 was calculated for the questionnaire.

The researcher and the research assistants both administered the questionnaire to the respondents before the training begins. Two hundred and forty-five copies of the questionnaire were administered and all were retrieved. After that, the training begins, the training was for three hours for each, thrice a week. The training lasted for a month. Immediately after the training, the focus group discussion was conducted with the participants to ascertain the impact the entrepreneurship training has made on the perception of the participants regarding the entrepreneurial skills acquired for poverty reduction. The quantitative data collected were analysed using mean and standard deviation for the research questions while the qualitative data were analysed using content analysis to determine the relevant themes.

\section{Results}

Research Question One: What is the perception of youths on the level of entrepreneurial skills needed for business creation and sustenance before the training in Bokkos LGA of Plateau State?

Table 1: Mean and standard deviation of the perception of youths on the level of entrepreneurial skills required for business creation and sustenance before the training

\begin{tabular}{llrrr}
\hline S/N & $\begin{array}{l}\text { Extent to which the following entrepreneurial skills are } \\
\text { needed: }\end{array}$ & $\mathrm{X}$ & $\mathrm{SD}$ & Remark \\
\hline 1 & Communication & 2.62 & 1.10 & Highly Needed \\
2 & Environment monitoring & 2.62 & 1.10 & Highly Needed \\
3 & Problem-solving & 2.80 & 1.06 & Highly Needed \\
4 & Interpersonal & 2.80 & 1.15 & Highly Needed \\
5 & Decision making & 2.85 & 0.97 & Highly Needed \\
6 & Accounting & 2.52 & 1.15 & Highly Needed \\
7 & Marketing & 2.56 & 1.17 & Highly Needed \\
8 & Human resource management & 2.56 & 1.14 & Highly Needed \\
9 & Customer reflection & 2.63 & 1.11 & Highly Needed \\
10 & Innovation & 2.63 & 1.11 & Highly Needed \\
11 & Risk management & 2.80 & 1.06 & Highly Needed \\
12 & Persistence & 2.42 & 0.98 & Moderately Needed \\
13 & Leadership & 2.80 & 1.10 & Highly Needed \\
14 & Resilience & 2.65 & 1.15 & Highly Needed \\
15 & Organizational & 2.62 & 1.10 & Highly Needed \\
\hline Weighted Average & $\mathbf{2 . 6 6}$ & $\mathbf{1 . 1 0}$ & Highly Needed
\end{tabular}

Analysis of data in Table 1 reveals that the respondents agreed all the entrepreneurial skills are highly needed Communication(mean $=2.62)$, Environment monitoring(mean $=2.62)$, Problem-solving $(\operatorname{mean}=2.80)$, Interpersonal $($ mean $=2.80)$, Decision-making $($ mean $=2.85)$, Accounting $($ mean $=2.52)$, Marketing $(\operatorname{mean}=2.56)$, Human resource management $($ mean $=2.56)$, Customer reflection $($ mean $=2.63)$, Innovation $($ mean $=2.63)$ and Risk management(mean $=2.80)$. The table shows that the youths indicated that persistence skill is moderately needed (mean $=2.42$ ). The respondents also indicated that Leadership, Resilience and organizational skills are highly needed $($ mean $=2.80),($ mean $=2.65)$ and $($ mean $=2.62)$ respectively.Generally, the Tableindicates that the respondents agreed that all the entrepreneurial skills listed are needed for business creation and sustenance (mean $=2.66, \mathrm{SD}=1.11$ ).

Research questions two was answered using qualitative data gathered from the focus discussion.

Research question Two: What are the training experiences of youths on the entrepreneurial skills acquired for business creation and sustenance to reduce poverty among youths in Bakkos LGA of Plateau State?

The theme on this research question is Training experiences on entrepreneurial skills for poverty reduction. Two hundred and thirty-eight participants were involved in the focus group discussion after the training out of the 245 participants, some the participants did not turn up.

All the participants $100 \%$ indicated that indicated that all the entrepreneurial skills listed in Table 1 before the training are needed for venture creation and sustenance. The participants were further asked, what are theirtraining experiences on the entrepreneurial skills acquired for business creation and sustenance to reduce poverty. Almost all the respondents said that they have acquired a bit of each of the listed entrepreneurship skills in Table 1. The participants were further asked whether they have acquired any other entrepreneurship skills apart from the ones listed. Specifically, 175 participants representing $73.5 \%$ of the participants stated that creativity skill 
is one of the most important skills they have acquired for successful entrepreneurship for poverty reduction. They stated that as an entrepreneur you must create something different from what others are doing. Also, 210 participants representing $88.2 \%$ said that they have acquired planning skill for successful entrepreneurship to reduce poverty. One hundred and fifty-seven participants representing $66.0 \%$ talked about general management skill in the content of the training. From their responses, participants affirmed their development of management skills in addition to the other skills for their venture creation acquired from the training. Some participants $169(71.0 \%)$ talked about resilience skill which they said they do not understand it before the training, they said it is a very important skill because it will help them not to give up in the face of any circumstances. These participants said that they have acquired this skill in the course of the training.

The participants were also asked to rank the entrepreneurial skills listed in Table 1 in order of importance. Majority of the participants $221(92.8 \%)$ gave a rank the entrepreneurial skills listed in Table 1 in order of the importance for successful entrepreneurship as follows: Innovation, Problem-solving, Risk management, Resilience, Persistence, Leadership, Organizational, Customer reflection, Decision making, Marketing among others. some participants talked about the skills they acquired which were not directly related to entrepreneurship butwere still beneficial. The skills acquired indirectly brings to the fore how extensive the training program was andits ability to satisfy diverse training needs of all participants.

\section{Discussion of Findings}

The study determined the impact of entrepreneurship training on poverty reduction among youths in Bokkos Local Government Area of Plateau State. The participants were given questionnaire on the entrepreneurial skills needed for poverty reduction. The study also found that decision-making $($ mean $=2.85)$, problem-solving $(\operatorname{mean}=2.80)$, interpersonal $($ mean $=2.80)$ and risk management $($ mean $=2.80)$ are some of the entrepreneurial skills needed by the youths for poverty reduction. The participants perceived before training that decision-making skill is highly needed by an entrepreneur. Without proper decision-making, the entrepreneur will not be able to succeed because doing business is all about decision-making. The participants also indicated that problem-solving, interpersonal and risk management skills are crucial for entrepreneurship. This finding supports the earlier finding of Orah (2019) who listed communication, environment monitoring, problem solving, technology implementation and use, interpersonal and organizationalskills as important skills needed for successful entrepreneurship. This finding also corroborates Itua (2018) who opined that management skills which are essential to the day to day management and administration of the business; part of these management skills is decision making skill. Also, entrepreneurship skills which involves problem- solving skill are very important for successful entrepreneurship.

The findings of the study also revealed that entrepreneurship training has positive impact on the entrepreneurial skill acquisition for poverty reduction among youths. This implies that entrepreneurship training has helped the youths who participated to acquire entrepreneurship skills that will lead to poverty reduction. This finding is in line with Okyireh andOkyireh(2016) who found that participants affirmed their development of moral principles in addition to the requisite skills for their jobs acquired from the training. They went further to state that training is a good way to acquired relevant skills for job performance. Participants exposed to the training have acquired entrepreneurial skills of resilience, creativity, planning, leadership among others. This shows that organizing training for youths is very beneficial for them to acquire necessary skills that will make them useful in the society. This finding also corroborates Udo (2016) who stated the acquisition of adequate practical skills is a means of increasing the productive power of any individual or nation and hence, a means to boosting sustainable development of entrepreneurship in Nigeria.

\section{Conclusion}

The study revealed that the entrepreneurial skills needed venture creation and sustenanceinclude:communication, environment monitoring, problem-solving, interpersonal, decision-making,risk management,persistence and leadership. It also revealed entrepreneurship training has positive impact on entrepreneurial skill acquisition. Based on these findings, it was concluded that entrepreneurship training has positive impact on poverty reduction among youths. This is because when youths acquire the right entrepreneurship skills, they will be able to utilize it and then poverty will be a thing of the past. The implication of these findings is that when youths are expose to entrepreneurship training, it will give them the relevant entrepreneurial skills. When these acquired skills are put into practice by the training participants, it can go a long way to change their financial status for better.

\section{Recommendations}

Based on the findings of the study, the following recommendations are made:

1. There is need for potential youth entrepreneurs to acquire entrepreneurial skills such as communication, environment monitoring, problem-solving, interpersonal, among others.

2. Government at all levels, Non-governmental organizations and philanthropist should organize entrepreneurship training programme for youths to acquire relevant entrepreneurial skills which will go 
a long way to reduce poverty among the youths.

\section{References}

Adejo, A.M. (2006). Poverty in the Land of Plenty. in NUBESS Journal of Contemporary Issues, 1(2).

Edoh, T. (2003). Poverty and the Survival of Democracy in Nigeria in Nigerian Journal of Political and Administrative Studies. 1(4).

Ajulor, O. V., (2013). Policy implementation and rural poverty reduction in Nigeria (An analysis of the NAPEP in Ado-Odo Ota L.G.A Ogun State. Ist Annual International Interdisciplinary Conference 24-26 April Flores Portugal 237-244

Bannock, J., (2008). A critical examination of the EO-performance relationship. International Journal of Entrepreneurial Behaviour \& Research,16(4), 309-328.

Evans, R. (2011). An investigation of the entrepreneurial orientation, context and entrepreneurialperformance of inner-cityJohannesburg street traders. Southern African BusinessReview, 15(1), 28-48.

International Labour Organization (ILO, (2013) Global Employment Trends for Youths. A generation at risk, Geneva.

Itua, G. E (2018). Entrepreneurship laboratory for entrepreneurial skills acquisitun and sustainable development in Nigeria. Okene Vocational Education Journal (OVEJ), 4(1),97-100.

Kankwanda, M. (2002). Poverty Eradication: Where Africa Stands. London: Economica

Leedy, P.D. \& Ormrod, G.E. (2009). Practical Research: Planning and Design. (9th ed.). New York, N.Y.: Prentice Hall.

Madsen, E.L. (2007). The Significance of Sustained Entrepreneurial Orientation on Performance of Firms - A Longitudinal Analysis.Entrepreneurship \& Regional Development. 19 (2), 185-204.

Mason, M. C., \&Gos, L. (2014). The role of agglomeration in entrepreneurship: empirical evidence from Italy. International Journal ofEntrepreneurship and Small Business, 21(1), 33-54.

Moreno, A. M., \& Casillas, J. C. (2008). Entrepreneurial orientation and growth of SMEs: A causal model. Entrepreneurship Theory andPractice, 32(3), 507-528.

Nwazor, J.C. \& Odigili, C.B. (2015). Determination of entrepreneurial skills needed by university business education graduates for successful entrepreneurship in Delta State. NAU Journal of Technology \& Vocational Education (NJTVE), 1(2), 86-95.

Okyireh, R.O., \& Okyireh, M.A.A., (2016). Experience of Social Media, Training and Development on WorkProficiency: A Qualitative Study with Security Personnel. Journal of Education and practice 7(30), $122-127$

Orah, J.O.C., (2019). Business education graduate entrepreneurs' rating of entrepreneurial skills utilization in entrepreneurship in North Central States, Nigeria. Unpublished PhD Thesis. Kwara State University, Malete, Nigeria.

Saba, T.M., Mamman, J.S., Saba, H.A \& Mustapha, A. (2020) Participation of Rural Women in Vocational Training Programmes in Northern Nigeria. Africa Journal of Technical \& Vocational Education \& Training, 5(1), 41-51

Udo, M.P. (2016). Principles and Methods in Nigerians Vocational Business Education. Pankshin: Grace International Academy Publishers.

Umoru, T.A., Oladunjoye G.T., Nwabufo N.B., Mamman J.S., Muhammed, Y.K., (2015). Poverty Vulnerability Among Rural Farmers in Baruten Local Govt. Area of Enugu State, ETF Country Wide Research Grant Proposal.

Wang, C. I. (2008), "Entrepreneurial Culture, Learning Orientation and Firm Performance. Entrepreneurial Theory and Practice, 32 (4): 635-657

World Bank, (2015) "Doing business in 2006 - Creating jobs” Annual Report, Washington D.C. 